\title{
The Diversity of Land Markets and Regulations in Europe, and (Some of) Its Causes
}

\begin{abstract}
The creation of optimal land institutions attracted renewed attention in the 1990s because of its central role in the transition process in former Communist countries in the former Soviet Union and Eastern Europe and more recently because of large-scale land investments in developing countries. This paper documents the existence of large variations in land institutions (markets and regulation) using current and historical data from Western and Eastern Europe. It then offers some hypotheses to explain these differences and draws implications for the role of land institutions in development (with reference to the current debate on large scale land acquisitions).
\end{abstract}

Keywords: Institutions, regulation, land markets, Europe

\section{Introduction}

There is a vast literature on the role of land rights and institutions for land exchange in the process of development (see e.g. Binswanger et al., 1995; Platteau, 2000; Keefer and Knack, 2002; Deininger, 2003 for reviews). The creation of optimal land institutions attracted renewed attention in the 1990s because of its central role in the transition process in former Communist countries in East Asia, the former Soviet Union and Eastern Europe (Lerman et al., 2004; Rozelle and Swinnen, 2004); and more recently because of the large-scale land investments in developing countries (Deininger 2013).

While much of the (policy) attention in the transition processes of the 1980s and 1990s was on the role of private land ownership and land markets, the growing demand for large scale land acquisitions in the 2000s has turned (policy) attention more towards ensuring access to land by traditional users in the face of new demands by (wealthy) investors. 
Recommendations for private ownership of land and the stimulation of land (sales) markets are based on the arguments that (a) land sales transfer full rights to the new user, (b) they increase access to credit as owned land can be used for collateral purposes, and (c) they provide optimal incentives for investment by providing permanent security of rights (Binswanger et al., 1995; Deininger and Jin, 2003). However, it is well understood that the functioning of land markets is strongly affected by uncertainty, transaction costs, and imperfections in input, product, capital and insurance markets (Carter and Zimmerman, 2000; de Janvry et al., 2001; Boucher et al., 2004). With substantial market imperfections, other forms of land exchange, such as rental markets, can play an important role. Hence, the functioning and development of land markets may therefore depend on the state of the surrounding economy and other markets (Sadoulet et al., 2001).

However the question of state versus private ownership of land oversimplifies the issue of land governance. Also in economic systems where land is privately owned and exchanged through markets, government regulations of these markets may importantly affect land allocation, the efficiency of land use, and the distributional consequences for income distribution. For example, as Vranken et al. (2011) show, regulations on minimum sizes for land use and transactions in Bulgaria have an important impact on land use.

Government regulations may also influence the relation between land sales and land rental markets. An extreme example of such regulation is when governments prohibit sales of land but allow renting of land. This is, for example, the case in Ukraine (Visser and Spoor, 2011). However, also regulations that influence the use of land as collateral or the security of tenants' rights may influence the functioning of land markets. A central element in the choice between buying land and renting land is 
the trade-off between security of operation (access to land) and liquidity (allocation of capital) (Vranken and Swinnen, 2006). This trade-off can be affected by government regulations which affect either tenure security or access to capital for farmers. When land rental markets are heavily regulated and tenants highly protected (such as for example in Belgium), renting can also provide tenure security so that farmers will prefer rental over buying (Swinnen, 2002).

The importance of land reforms in the transition process in Eastern Europe and in Asia has yielded a large number of studies on land reforms and their effects (e.g. Lerman et al, 2004; Rozelle and Swinnen, 2004). Questions about land reforms in Latin America and specific land institutions in Africa have also yielded important insights (e.g. de Janvry and Sadoulet, 1989; Platteau, 1992; Deininger, 1999; Toulmin and Quan, 2000).

However, there is very little comparative information on the nature of land markets and on their regulation. Such comparative data can be an important source both for studying the relative efficiency and the effects of land regulations, as well as for analysing their determinants, i.e. the political economy of land institutions.

One part of the literature explains differences and changes in land tenure as an endogenous response to changes in the external environment (Boserup, 1965; Deininger and Feder, 2001). Others question the hypothesis that changes in land institutions are efficiency-driven and argue that there is no assurance that an institution will emerge simply because it is more efficient than the existing alternatives (Baland and Platteau, 1998). Changes in land institutions also imply redistribution of wealth and rents, and often of economic power and political influence. The emphasis on distributional aspects of institutional change underlies 
studies on the political economy of land reforms (Bardhan, 1989; de Janvry, 1981; Swinnen, 1999, 2002).

Historical changes, such as major political reforms in the early $20^{\text {th }}$ century and the late $20^{\text {th }}$ century liberalization process in East and Central European transition countries, provide a "natural experiment" to study the formation of land institutions, and to analyse how in the historical-evolutionary process the institutional forms adapt and mutate (or not) in response to the changing circumstances (Swinnen and Rozelle, 2009).

In this paper we present comparative indicators on land use and regulations for several countries in Europe, and provide a series of hypotheses to explain the variation in land markets and land regulations. After presenting a conceptual framework (section 2), we show that there is large variation in land governance (how land is exchanged and what is regulated by the state) even in countries which are relatively close in their economic development, geographic location and political institutions. We document this using current and historical data from (Eastern and Western) EU member states in section 3 and 4. In section 5 and 6, we present some hypotheses to explain the observed differences and use a political economy lens to analyse these changes. In the final section we draw implications for the role and optimality of land institutions in development (with special reference to the current debate on large scale land acquisitions), and we discuss the limitations of our study.

\section{Conceptual Framework: Rental vs. Sales Markets and the Role of Regulations}

Land transactions can play an important role in economic development. First, they provide land access to those who are productive but own little or no land. Second, they allow the exchange of land as the off-farm economy develops (Yao, 
2000). Third, they facilitate the use of land as collateral to access capital markets (Deininger and Feder, 2001). The form of these transactions matters. The most straightforward distinction is between the sale of land and renting of land.

\subsection{Benefits and problems of land sales markets}

Theoretically, the sale of land is often considered the superior form compared to land rental. The arguments supporting the optimality of land sales are that (a) land sales transfer full rights to the new user; (b) they are more likely to increase access to credit as owned land can be used for collateral purposes, and (c) they provide optimal incentives for investment by providing permanent security of rights (Binswanger et al., 1995). However, these conclusions rely on a number of simplifying assumptions which are not always consistent with reality, and especially not with reality in transition and developing countries.

Imperfections in input, product, capital, and insurance markets affect the functioning of land sales markets. Capital market imperfections may constrain the efficiency of land sales markets in several ways. First, where capital markets work imperfectly, land purchases typically have to be financed out of own savings. Second, where financial markets do not work well, or where confidence in money as a repository of value is low, land may be used to store wealth and may be acquired for speculative purposes. Third, in many developing and transition countries, financial institutions do not accept land as collateral because of property right problems or problems in repassing and selling land (Swinnen and Gow, 1999). Fourth, land may be purchased, or held on to, as a hedge against inflation, or as an investment asset in the absence of alternative investments or hedging options. Fifth, with constrained access to credit, investment in land ties up much needed capital in land, and prevents 
farmers from using these savings for investment in technology, equipment, or quality inputs. Finally, people hold land for many other reasons than production, such as prestige value, lifestyle value and family traditions, leading wealthy and politically connected households to accumulate large tracts of land. Some of these factors also make the sale price of land typically higher than the productive value of land (Binswanger et al., 1995).

In addition, transaction costs in land sales can be large. This does not only refer to notary fees, etc., but also to the costs of enforcing property rights, getting access to the necessary documents and approval from local officials, which may be costly for reasons of corruption or inefficient administration. Transaction costs not only imply that a premium needs to be paid by the buyer, but also that significant losses can be incurred by buying and re-selling of land, and hence prevent flexible adjustments of land use through land sales (Carter and Zimmerman, 2000; de Janvry et al., 2001).

As a consequence, rural land sales markets are typically thin in low income countries. In some cases, land sales may even be limited to distress sales. Returns from agricultural production are highly covariate. Therefore, land prices will be high in good years when savings are high, sellers are few, and potential buyers of land are many. In contrast, when incomes fall, demand for land is low. However, the need to satisfy basic subsistence constraints could give rise to a large supply of land from people who are forced to sell their land to survive (Sadoulet et al., 2001). Hence, in areas with poorly developed insurance and capital markets land sales may be limited to distress sales.

All this has important implications for efficiency. An efficient land market would transfer land from less to more productive users of the land. As these constraints on the land market limit the transfer of land from less efficient to more 
efficient users, efficiency losses are incurred. As owners hang on to land for reasons of high transactions costs, speculation, insurance, or wealth hoarding, land will not be used in the most productive way.

Constraints on land sales markets are not only important for the efficiency of the land market, but also for poverty reduction. In many cases, the poor are disproportionately affected by imperfect capital and insurance markets. Also, the role of land as a source of hedging and wealth is more important for them. As a consequence, these imperfections tend to reduce disproportionately the benefits which poor people could obtain from participation in land markets.

\subsection{Benefits and constraints of land rental markets}

In a review Deininger (2003) concludes that "transaction costs, risk and portfolio considerations, limited access to credit markets, and the immobility of land all imply that the actual performance of land sales markets may be far from the theoretical ideal" and that "land rental markets, including share tenancy, can go a long way toward bringing the operational distribution of holdings closer to the optimum, given existing constraints”.

The potential of rental markets is (a) to allow more flexible adjustments of the land area used with relatively low transaction costs; (b) to require only a limited capital outlay, thereby leaving more liquidity available for productive investments rather than locking it all up in land; (c) to facilitate easy reallocation of land towards more efficient users than the current owners; and (d) to provide a stepping stone towards land ownership by the landless. ${ }^{1}$

Several of these advantages are especially relevant for transition and developing countries. Transaction costs for land sales were very high during transition, if sales 
were permitted at all. Also, flexible exchange options are particularly important in conditions of uncertainty. During transition, farms and land owners were often uncertain about how market conditions would evolve, and how institutions and laws would evolve. In such conditions flexible and short term rental contracts may be better choices than sales or long run contracting - for both sides of the transaction.

Rental markets have problems as well. There can be problems with investment incentives because of the lack of long run security. However, empirical studies show that the impact of land ownership (and hence the benefit of land sale versus rental) on efficient investment incentives because of enhanced security is often surprisingly small (Carter et al., 1994). There are several reasons. First, what may appear to be precarious land rights to external observers may actually be long-term entitlements in the specific context of these societies. Second, sufficient investment incentives can be provided by use rights that are granted to the land users for a certain period (Braselle et al., 2002). Third, in some cases there is bi-causality between investments and security: tenants invest in land-related assets (trees, land improvements) to enhance their security. Finally, this investment effect will also depend on the nature of the investments, and one should expect the length of the investment depreciation to be correlated to the length of tenure security required.

A second potential weakness of renting land is that it does not enhance access to credit because rented land cannot be used as collateral. However, this credit-supply effect is strongly conditional on the existence of rural financial institutions and on the willingness of these institutions to accept land as a collateral - which they often do not (Swinnen and Gow, 1999).

Third, insecure property rights are not only a problem for sales markets, but also for rental markets. Weak property rights or high transaction costs - often in 
combination with the absence of reliable conflict resolution mechanisms may cause substantial costs for owners to enforce their rights on the land once they rent it out to tenants (Skoufias, 1995). This reduces the incentives for owners to rent out or reallocate their land. This problem often results in segmented land rental markets with renting taking place between agents where rights enforcement can occur through different mechanisms - such as social pressure or family ties (Macours et al., 2010; Vranken et al., 2011).

\subsection{Optimal mix of rented and owned land}

A crucial element in the sales versus rental market choice is the trade-off between security of operation and liquidity. In Europe and the USA, many farms have both owned and rented land, and the proportion of such mixed land use increases with the size of the farm (Feenstra, 1992). A minimum amount of owned land ensures security of operation and security for long term investments while extending the farm by rented land allows capital otherwise invested in land to be used for investing in other productive assets (Sommer et al., 1995). In a capital intensive production system, with the possibility of using other assets as collateral, farms prefer to invest in new technology and farm-specific assets rather than tying up large sums of capital in land purchases. In this way, farms can combine tenure security (with their assets and long term investments concentrated on owned land) on the one hand and flexibility in land allocation, and freeing up capital for other investments (by renting additional land rather than buying) on the other hand (Vranken and Swinnen, 2006).

The optimal mix of rented and owned land is affected by factors that affect the operational security and/or the liquidity constraints. Key factors are capital market imperfections, farm profitability, and government regulations. For example, 
government regulations which enhance tenant rights may stimulate both land renting (by improving security of property rights) and investments in rented land. In some European countries governments have introduced legislation to enhance tenant rights, e.g. by guaranteeing a minimum length of rental contract of several years in order to guarantee tenants sufficient security of land operation. Regulations obliging land owners to compensate tenants for investments tenants made in land improvements enhance the right of first purchase, further enhance the tenant's incentives to invest in rented land.

\section{Land Markets in Europe}

Figure 1a shows that there are major differences in the role of land sales and rental markets between countries in Europe. In the European Union of 27 countries, a union of countries with a fully integrated (agricultural) market and a common agricultural policy for the past 50 years, the share of rented land in total agricultural land varies from less than $20 \%$ to more than $80 \%$. What is even more remarkable is that the differences are not closely correlated with geographic location or large geoinstitutional history, such as between Eastern "new” member states and Western “old” member states. In fact, as Figures $1 \mathrm{~b}$ and 1c show, the variation in each of these blocs is almost as large as in the EU-27 as a whole. For example, in Western Europe the share of agricultural land rented by farmers varies from less than $20 \%$ in Ireland to around $70 \%$ in Belgium and France (Figure 1b).

Also the historical evolution can vary strongly. Table 1 documents changes in land renting in Western European countries. The importance of land renting has remained almost constant over 150 years in Belgium (around 70\%). In contrast, in Ireland the share of land rented decreased dramatically from $96 \%$ in 1885 to $6 \%$ by 
1930 and increased somewhat (to 16\%) by now. In England, the share of rented land has declined very strongly as well, but more gradually: from $89 \%$ in 1910 to 32\% now. In the Netherlands, the share of rented land was relatively constant between 1900 and 1960 (around 50\%) but has halved since then (27\% now).

In the Eastern European countries land governance changed dramatically over the past 25 years. Under the Communist regimes land was mostly managed by huge collective and state farms ${ }^{2}$, and land transactions were controlled, and often forbidden, by the state. Over the past decades, most of these countries reformed their land rights and tenure systems and deregulated land exchange. All countries started from a common central-planning economy and they all went through a process of land reform and farm restructuring. However, there were large differences in the reform choices and the way the reforms are implemented, which resulted in the current differences in land markets across countries. In Eastern EU countries like Czech Republic and Slovakia the vast majority (80-90\%) of agricultural land is rented, while in other Eastern EU countries like Poland and Latvia much less land is rented (20-30\%) (Figure 1c). Moreover, the differences cannot be simply related to regional or broad political-institutional differences as there are major differences between countries in the same sub-regions (e.g. Slovakia (89\%) versus Slovenia (27\%)) (Swinnen et al., 2006).

\section{Land Regulations in Europe}

Not only are there major differences in the nature of land markets in Europe, both over time and across countries, but there are also major differences in regulations of land exchanges. In some countries, land prices, sales and rental contracts are regulated by the government, in others not. 
To assess the importance and stringency of land regulations and to indicate the differences between countries, we have collected data on land regulations based on 15 variables, which we grouped in four sub-indicators: (1) measures to protect the tenant or the Tenant Protection Index (TPI); (2) measures to protect the owner-cultivator or the Owner Protection Index (OPI); (3) measures to protect the owner; and (4) measures to prevent fragmentation. In addition, we also consider the aggregate Land Regulation Index (LRI). All variables and indicators are discussed in detail in Swinnen et al. (2014). The information on the variables is obtained from (structured) interviews with local land experts in each of the countries and from a series of country studies of land markets (Ciaian et al., 2010). All information refers to the regulations that were in place in 2011.

The sub-indicators and the total regulatory indicator (TRI) are presented in Figure 2. The indicators reflect the large differences among the EU countries in land market regulations, and again the variation in interventions is not a simple East-West divide. Both among the new and among the old Member States there are strongly regulated and very liberal approaches in land governance.

For the 24 EU countries for which we have data, the most regulated land “markets” are in France (TRI = 9) and Hungary $($ TRI = 8). In France, regional organizations - the so-called “Societés pour l'Aménagement Foncier et l'Etablissement Rural (SAFERs)" - determine a minimum and maximum price bracket within which the tenant and the owner can agree a contract price. These organisations effectively control the local land markets through their powers to buy, sell and rent out agricultural land. Effectively, they ensure that land is only owned by working farmers. The SAFERs also control the level of farm restructuring and growth by requiring farmers to get authorisation from them for farm expansion (Latruffe et 
al., 2013). In Hungary, land can only be owned by individuals or families ("natural persons”) - not by farming companies which operate a large share of the land. Ownership is restricted to Hungarian nationals and owners have an obligation to farm the land. The most liberal regulations exist in Ireland $(\mathrm{TRI}=0)$, Greece $(\mathrm{TRI}=0.25)$, and the UK (TRI $=0.5)$ among the old Member States and in Romania $($ TRI $=1.5)$ and Czech Republic (TRI = 2.5) among the new Member States.

The aggregate numbers may bias to some extent the conclusions, in particular for countries with medium levels of the TRI. For example, Belgium has a TRI of 5 but all the regulations are in the rental market, which is very important in Belgium (approximately $70 \%$ of the land is rented) and which is highly regulated: the tenant protection indicator (TPI) is 5 which is the highest of all countries (together with France). However, they have no other regulations (the other indices are all 0). The Netherlands is similar to Belgium in that it has quite significant regulations in the rental markets to protect the tenants $(\mathrm{TPI}=5)$ but almost no other land regulations. This contrasts with France which has extensive regulations both in the rental and in the sales markets.

Another example is Poland. Poland's TRI is 6.5, but there is a large difference between the sales and rental market regulations. In Poland, where most of the land is owned and operated by (small) family farms (only $20 \%$ is rented), there is very little protection for tenants $(\mathrm{TPI}=1$ ) but significant regulations protect (family) farms who operate on land they own: their owner protection index (OPI) is 3.5. Together with Hungary, where the OPI $=5$, this is the highest of all countries.

Figure 3 summarizes these different regulatory "patterns": France has a high regulatory index for both rental and sales markets. Belgium and the Netherlands have a high regulation index for rental markets but not sales markets; and Poland and 
Hungary vice versa. Then there is a group of countries (including Ireland, Greece, the UK, Finland, Germany and the Czech Republic) with very little regulations in either land rental or sales markets.

\section{Hypotheses to Explain Differences in Land Governance}

In a first step to derive some hypotheses on the reasons for these large variations in land markets and regulations in Europe, we look at the correlation between the share of land renting and the TPI. Figure 4a shows that there is a positive correlation for the EU as a whole, but that the relationship is weak.

When we split the EU countries in West (old member states - Figure 4b) and East (new member states - Figure 4c), we see that the relationship is much stronger in the Western countries than in the Eastern countries. In the Western member states there is a positive relationship between the extent of regulation of land rental markets (mostly protection of tenure security) and the importance of land rental markets. This is not the case in new (Eastern) member states.

We first discuss hypotheses to explain the relationship in the Western countries, and afterwards discuss potential reasons for the lack of correlation between regulation and land markets in the Eastern countries, and for other observed forms of variations in land markets and regulations.

\subsection{Land regulations and tenure security in Western Europe}

To understand the current situation of land exchange and regulations, it is insightful to consider the historical evolution of these land market governance arrangements. The importance and nature of land renting and of the regulations has changed significantly throughout history. 
We draw on Swinnen (2002) who explains (a) the historical development of a positive relationship between land renting and tenure regulations as the result of economic and political changes in the late $19^{\text {th }}$ and early $20^{\text {th }}$ century; and (b) the weakening of this relationship in the second half of the $20^{\text {th }}$ century with perverse effects of tenure regulations.

Land governance and political reforms in the $19^{\text {th }}$ and $20^{\text {th }}$ century

Historically, European countries were dominated by large (rich) landlords renting land to small and poor tenants with weak bargaining power for tenants, resulting in poor tenure security and few tenant rights, albeit with some variations across the region. The demand for improved tenure rights was reflected in the demand for the three F's ("Fair rents, Fixity of tenure, and Free sales") since land owners determined terms of setting the length of tenure, the rent, the use of the land (crop patterns), and captured land investments made by tenants.

Political reforms and economic upheavals caused major changes in land institutions and exchanges in several Western European countries (Swinnen, 2002). These political changes were intertwined by dramatic changes in the economy. One key factor was the strong declines in world market prices for farm products, inducing distress sales of land by small farmers in the late $19^{\text {th }}$ and early $20^{\text {th }}$ century. These negative market developments triggered a major social upheaval and political pressure to enhance the situation of small farmers and tenants (Tracy, 1989; Swinnen, 2010).

Pressure for changes had little effect in the $18^{\text {th }}$ and $19^{\text {th }}$ century since landlords dominated many governments in Europe. However this political economic equilibrium changed with industrialization and democratization, in particular the distribution of voting rights to workers, small farmers and tenants. The combination 
of improved political representation by tenants, economic changes and social upheaval resulted in policy reforms and new regulations giving tenants (and landless labour and small farmers) more security of operation and improved access to land.

However, there was more than one way to improve tenants' land rights. One can, in broad terms, distinguish two types of policy strategies to improve the situation of the tenants. ${ }^{3}$ The first strategy was to improve the rental conditions for the tenants through regulations, including better conditions in case of contract termination, such as compensation for land improvements and automatic rights for rent renewal and preemptive rights. The second strategy was to help the tenant become the owner of the land through government subsidies to buy the land (stimulating the demand for land) or through increased land and inheritance taxes (stimulating the supply of land).

The first strategy was followed in countries such as Belgium, France and the Netherlands, where rent regulations were introduced which focused primarily on improving the tenure security for farmers. These were not introduced all at once, but incremental increases throughout the $20^{\text {th }}$ century led to a situation where farmers no longer wanted to purchase land since their tenure security was very high, and they could use their capital for other investments.

This explanation is consistent with our earlier observations of today's land governance. In Belgium, France, Italy and the Netherlands, the rental share is relatively high and rental markets are highly regulated, with strong protection of the tenants. The TPI equals 4 to 5 in these countries (see Figure 2). Rental contracts have minimum lengths and are automatically extended. Moreover, landowners can only get the land back for specific purposes, such as when they want to farm the land themselves, or if the land is to be converted to alternative uses, which may have to be in the public interest. In the Netherlands, state land committees ("grondkamers") can 
directly intervene in regulated rental contracts, impose extension of rent contracts, and decide the rental price. ${ }^{4}$ Also in Belgium and France, local committee-based rent controls exist. In Belgium maximum prices are set by committees, comprised of farmers, land owners and government officials.

The second strategy, i.e. to help tenants become land owners, was the dominant strategy in countries like Ireland and Denmark. There, the government set up state funds to purchase farms for poor tenants, and/or to subsidise the purchase of land by poor tenants, either directly or through regulating land sales prices, through subsidised loan conditions, or through tax benefits for purchasing land. This strategy caused a strong shift from land renting to ownership by farmers. The most dramatic impact occurred in Ireland where almost all land was rented in the beginning of the $20^{\text {th }}$ century, but this share declined to $6 \%$ in 1930 - and around 16\% today. In Ireland the debate for improved tenure security was interrelated with the independence struggle: it was a conflict between Catholic Irish tenants versus (mostly absentee) Protestant English landlords. This additional factor made the conflict more extreme and violent. After 1876 falling agricultural prices induced a dramatic increase in violence. The extension of voting rights to farm workers and tenants in 1885 resulted in several land laws which allowed an increase in land ownership of small farmers (Guinnane and Miller, 1997). After Ireland became independent in 1921, virtually all land was transferred to small farmers and the share of leased land fell to 6\%, by far the lowest anywhere.

This explanation is also consistent with our earlier observations that today in countries which helped tenants to become land owners, and where land ownership is the dominate form of land use in farming, land rental regulations tend to be less stringent. ${ }^{5}$ Examples are Ireland and Denmark: the TPI is less than 1 (see Figure 2). In 
Demark the only requirement for renting is to have a written rental contract. There are no restrictions on minimum duration, rent prices, etc.

In England $(\mathrm{UK})^{6}$, improvements in the situation of tenants followed from a mixed approach. The decline in political power of the large landlords, resulted, first, in important changes in the rights of tenants, such as the right to determine crop rotations and the right to determine purchases and sales of farm products, and the right for compensation if they were to leave the land. Later on, additional rental regulations were introduced, as well as the creation of Land Tribunals for resolution of conflicts between landowners and tenants. The second major change was the increase of land and inheritance taxes and the shift of income taxes from tenants to landlords. In combination, these policy changes contributed (a) to better and more secure rights for tenants, and (b) to a decline of tenancy as landlords sold their land to tenants.

In summary, the predictions of this historical political economic explanation are largely consistent with our earlier observations. It implies that similar policy objectives lead to different regulations and land market situations in Western Europe. One could think of the different regulation-market combinations as different equilibriums in (capitalist) market economies which have persisted for a long time despite their integration in an economic union and a common agricultural policy. However, the relationships are not perfect and have undergone dynamic adjustments. In particular important adjustments in land regulations occurred in the second half of the $20^{\text {th }}$ century, and in recent years. 


\section{Adjustments in tenure regulations to address perverse effects}

While initially the tenure regulations enhanced the rights of tenants and their access to land, later on some of the distortionary impacts created perverse effects. In West European countries with extensive regulation of land rental contracts, the regulations constrained re-allocation of land. This lead to perverse effects as landowners were no longer interested in renting land to farmers and preferred to sell it.

In countries such as France, Belgium, England and the Netherlands, tenure regulations gradually tightened in the course of the $20^{\text {th }}$ century in favour of the tenant as a result of the political economy dynamics explained above. The effect of the regulations can be seen from the gap between the prices of land with and without a rental contract in the Netherlands (Figure 5) and between the evolution of rental and sales prices in Belgium (Figure 6). In both cases market prices (for non-regulated land) increased much stronger than regulated land prices. The substantial gap between both prices indicates strong price distortions due to the regulations.

The regulations and price distortions became so strong that landlords no longer wanted to rent land to farmers. Hence, overregulation led to the paradoxical outcome that land rental decreased. For example, in the Netherlands and France, land renting decreased substantially as a consequence of these tight regulations. In the Netherlands, land rental has fallen from almost $60 \%$ after the Second World War to around $27 \%$ today (Table 1 ).

In response to these developments, countries relaxed some of the regulations. In France, rental regulations were relaxed, which stimulated rental agreements again and renting increased significantly over the past 2 decades (see Table 1). The Netherlands relaxed the regulation in 2007. In addition to the traditional or regular tenancy 
contracts, which include provisions on the price, duration and some form of a preemptive right for the tenant, liberalised rental contracts have been introduced. The duration of these contracts can be freely determined by the owner and the tenant and in case a contract has a duration of less than six years, there are no price restrictions. In addition, for these contracts the tenant has no pre-emptive right. This policy change aimed to encourage land owners to lease out their land and to increase access to land through rental. However, up to now the share of rented land remained relatively stable (at app. 27\%) in the Netherlands and although the share of liberalised contracts has increased over the past 5 years (from 16\% to $28 \%$ of the rented land), the majority of the land is still captured in long-term regular rental contracts.

\subsection{Legacy of the Communist Era and Post-Communist Reforms in Eastern Europe}

The nature of the land markets in Eastern Europe cannot be understood without considering the communist control over land between 1950 and 1990. Virtually all countries have gone through some form of land reform and farm privatization and restructuring, heavily affecting their current land markets (Wegren, 1998; Meyers and Kazlauskiene, 1998; Tillack and Schulze, 2000; Rozelle and Swinnen, 2004). Yet the resulting land markets and land use differ strongly among countries.

Land reforms, farm structures and land markets

Various factors, including land reform procedures (who themselves are the result of political economy equilibriums) ${ }^{7}$, production factor endowments, market imperfections, existing institutions, and transaction costs have all affected the recent development of land markets in Eastern Europe (Petrick and Weingarten, 2004; Swinnen et al., 2006). 
In particular, there is a relationship between the organization of the farms and the development of land markets. The large differences in renting land between countries are related to the importance of corporate farms. For example, in the Czech and Slovak Republic $70 \%$ of the total agricultural land area or more is used by corporate farms. Also in Hungary and Bulgaria, corporate farms still use around half of all land. In contrast, corporate farms have virtually disappeared in countries such as Latvia and Lithuania, where less than $15 \%$ of the land is used by corporate farms. These differences have important implications for the development of land rental markets, since these farms rent most of the land they operate on. Figure 7 illustrates the strong positive correlation between the share of land rented in East European countries and the share of land used by corporate farms. There is almost a perfect linear relation, as illustrated by the fitted trend line and the high $\mathrm{R}^{2}$ of more than 70 per cent.

\section{Patterns of land market development}

Of course, the observed correlation says little about the causality of this relationship. To get a better understanding of potential causes and effects, we use the framework developed by Swinnen and Vranken (2007) and Macours and Swinnen (2002) in identifying several "patterns of land market development”.

One pattern (A) is that of capital intensive agricultural economies where land controlled by state and collective farms under the Communist regime was restituted to former owners and where large scale corporate farms continue to dominate. In these systems, after restitution, very extensive and active rental markets for land developed. Renting is mostly from households to large scale corporate farms, often based on formal contracts. 
Examples of this pattern are Slovakia and the Czech Republic (and parts of Hungary). In the Czech Republic and Slovakia the rental market is very active. Large corporate farms, who use more than $70 \%$ of the land, rent in $99 \%$ of their land, a significant part from households who are no longer active in agriculture and received land ownership through the post-communist land restitution process in the 1990s. Rental contracts are often formal and long term.

A very different pattern (B) is that of more labor intensive agricultural economies where land was either still owned by small farmers or where land was (at least partly) distributed in kind to rural households and where small scale family (household) farms dominate. There is relatively little land renting, mostly household to household and (initially) mostly informal.

Examples of this pattern within the EU are Poland and large parts of Romania. In Poland and Romania most agricultural land is operated and owned by farms, mostly small family farms. Less than $30 \%$ is rented (see Figure 1c). Initially, this land renting was short term and informal renting. However, renting has become more formal since EU accession because farmers can only receive EU subsidies for land on which they have formal rental contracts.

The comparison of these patterns suggest that the strong differences in land market developments result from a combination of factors: differences in privatization and land reform choices, and differences in technology and the role of agriculture in employment and in the economy. In Pattern A countries land was restituted to former owners, most of whom were no longer active in agriculture, with the share of agriculture in employment as low as $11 \%$ by the 1990 s. Farming was capital and land intensive: the labor/land ratio in the Czech Republic and Slovakia was around 0.13 workers per hectare. In combination the technology and land reform 
choice contributed to a consolidation of the large-scale farming structures, which use more than two-thirds of all land in the Czech Republic and Slovakia. These farms continued to use the land on which they had been operating, but now had to pay rents to the new owners. As farming companies, with formal administrations and official book-keeping, the farms use written rental contracts. The companies prefer longer term contracts as it provides them stability in their operations - and possibly locks the owners into lower payment contracts, as payments were generally low at the start of transition. Hence, with land mostly used by large farms and mostly owned by nonfarming households, who received the land through restitution, formal renting is very widespread.

In contrast, in Pattern B countries, agricultural employment was much higher: in Poland and Romania more than 25\% of total employment was in agriculture in the early 1990s. Farming was much more labor intensive: the labor/land ratio was 0.27 in Poland and 0.21 in Romania, about two times higher than in Slovakia and the Czech Republic. In Poland, farms owned (most of) this land throughout the Communist regime. In Romania, they received it through a combination of land distribution in kind to rural households and restitution. The combination of the land property rights distribution and the labor intensive technology caused the domination of small household farms who use much of the land. As a consequence, rural households themselves generally use most of the land they own.

\section{Land regulations and tenure security}

Unlike in West European countries, where rental regulations are stronger where renting is important, this is not the case in Eastern Europe. As Figure 4c illustrates there is no correlation between the land rental share and regulations to protect the 
tenant - unlike in Western Europe. The reason is the very different structure (and history) of the rental markets in Eastern (vs. Western) Europe, as explained above. As a large part of the renting in Eastern Europe is from small land owners to large farms - the opposite of what was the case in Western Europe historically - there was no political pressure from the tenants on governments to protect their operations and tenure security through regulation. The "power balance" in this (reverse tenancy) relationship is clearly very different than it was in Western Europe when the tenure regulations were introduced.

\section{Regulations restricting foreign land ownership}

The main land regulations in Eastern Europe are rules to prevent foreigners from purchasing farm land. In fact, if one accounts for these regulations the OPI reduces to 2 or less in all new member states (except 3 for Hungary). While these restrictions existed in all Eastern member states (with the exception of Slovenia) the implementation of the rules after accession has been quite different among the member states. There are differences in the way 'foreigners' are defined in the legal restrictions, and in the conditions that foreigners have to fulfill in order to (exceptionally) obtain ownership of agricultural real estate. The restrictions have been strongest in countries like Poland and Hungary, two countries with strong political representation of small farmers and bordering on (much) richer neighbors (Germany and Austria, respectively). ${ }^{8}$

While the restrictions on foreign ownership were expected to have a negative impact on the efficiency of land exchanges, land allocation and productivity growth, empirical evidence indicated that the impact was rather low. The potentially negative impact was mitigated by several factors (see Swinnen and Vranken, 2009 for a more 
detailed discussion). First, there are no restrictions on renting land to foreigners. This is important since land rental is widespread in the NMS, notably among larger farms, which are the kind of farms in which one would expect foreign investment. Second, there are exceptions to the restrictions on foreign ownership of agricultural land. For example, in Lithuania and four other countries, land ownership by foreign companies is not restricted and Estonia allows ownership without restriction up to a maximum amount. In several countries, there are also no restrictions on foreign ownership of land for intensive animal husbandry. In combination, these factors moderate the impact of the restrictions. For example, if foreigners can acquire farm buildings and the land on which these are built, this may allow combining renting and owning land for farm operations as is done in farming where there are no restrictions. Fourth, other factors constrain the functioning of the land markets in the NMS, such as high transaction costs (Dale and Baldwin, 2000). Finally, while the restrictions have held back the direct benefits of foreign investment, agriculture in the NMS has benefited extensively from large amounts of foreign capital in the food industry and agribusiness. These investments have had significant, positive spillover effects on the farms, as foreign companies have introduced technology, know-how and capital into the food chain, which has contributed to greater investment and enhanced product quality in agriculture (Dries and Swinnen, 2004; World Bank 2005).

\section{Lessons and Implications}

The first lesson is that there can be remarkable institutional diversity in countries with similar economic development, geographical proximity, and with integrated economies. Our analysis has shown that there is enormous heterogeneity in land markets and regulations in Europe. The diversity in how land is exchanged and 
in how land rights and exchange are regulated within a "single" agricultural market and a "common" agricultural policy in the EU is remarkable.

Another lesson relates to policy debates. Most of the discussions on land reform in Eastern Europe in the early 1990s focused (often implicitly) on the efficiency of land sales markets and land ownership. Yet, it is clear from our analysis that one should not focus exclusively, or even mostly, on land ownership and land sales. European history and the current land governance systems clearly illustrate that a modern agricultural system can thrive in a land tenure system when a large part of the land used by farmers who do not own (most of) the land. Security of operation can be sufficiently secured by tenure regulations without having to rely on land sales (or expropriations). Choosing between buying (owning) land and renting land implies a trade-off between security of operations, capital requirements, and shorter term contracts allowing for adjustments to reflect change in market conditions. The latter is particularly important in volatile or uncertain environments. For these reasons many farms prefer a mix of ownership and renting of land, where the optimal mix will depend on local institutions.

This is important since land reforms or expropriation for redistributive purposes causes major political problems. The experience from Europe shows that enhanced access to land and secure operation for small farmers can be achieved by a variety of policies. In some countries increased land and/or inheritance taxes played a major role, while in others such taxes were not important. The best policies can only be decided taking into account the local institutional constraints and the political economy. Yet since land reforms are politically very difficult, governments may want to concentrate on rental arrangements to ensure the basic conditions for successful farming to develop. 
However the experience in Europe also confirms that major policy reforms leading to effective changes in tenure systems may not be that much easier than land reforms and are also very politically sensitive and difficult to achieve. In fact, the major changes came about after two major political changes. In Western Europe this occurred with the empowerment of small tenants and farm workers by the extension of voting rights in the late $19^{\text {th }}$ and early $20^{\text {th }}$ century. The resulting changes in land markets and tenure regulations are still felt today. The Eastern European land markets of today are heavily determined by the dramatic changes after the fall of the Berlin Wall and their economic and political transitions.

Moreover, it is important to note that regulations to protect tenant rights may have quite different effects, and a very different political meaning, in environments where small (poor) tenants are renting from large (rich) landlords - as was the case in the early $20^{\text {th }}$ centuries in many European countries - than in environments where large farms are renting thousands of hectares from families, each renting out small plots of land - as is the case in several central European EU member states (like Slovakia and the Czech Republic). The "power balance" and the tenure security in this (reverse tenancy) relationship is clearly very different.

Another lesson relates to the restrictions that Eastern European countries imposed on foreign investment in their land markets. This may be particularly relevant for countries which are considering strategies of optimal governance for large scale land acquisitions by foreign investors - an issue which has risen to the top of the developing agenda with growing interests to invest in agricultural land in developing countries with rising food prices (Deininger, 2013). Countries in Eastern Europe in the 1990s and developing countries are different in some aspects, but similar in others. They have similar underperforming agri-food systems; technology 
and know-how at low levels; a need to integrate with international markets; poorly defined land rights and non-existent or imperfect land markets. (They are different in terms of incomes, infrastructure, and human capital endowments all of which were better in Eastern Europe).

Restrictions on foreign ownership constrain the inflow of much needed capital, know-how and technology for agricultural development. Yet a good combination of liberalization and regulation, for example by imposing maximal ownership and allowing secure rental agreements, may address both political sensitivities and allow much of the economic benefits to occur.

It is also important to point out that much of the benefits from foreign investment in agriculture come indirectly from the spill over effects of foreign investment in the food industry and agribusiness which led to improved access to finance, increased investments, and considerable technology and quality improvements of local farms (Dries and Swinnen, 2004). Similar effects can be observed in modern supply chains in developing countries (Maertens and Swinnen, 2009; Minten et al., 2009).

While this paper is the first attempt to provide a broad comparative review of land markets and their regulations, and to offer some hypotheses for the variations, the paper has obvious limitations. The data and indicators of both land markets and land regulations can be refined and fine-tuned. The analyses of the determinants of the land institutions and regulations are mostly based on observations of correlations, which cannot demonstrate causality. Mostly they offer hypotheses for further research to test the causal mechanisms behind the observed correlations. In summary, there is obviously much room for improvement and further research in this area. 
${ }^{1}$ Another potential advantage of rental contracts is to help overcome, through sharecropping contracts, market failures in labor, insurance, credit, management and supervision (de Janvry et al., 2001). However, this may be somewhat less important in countries where land is owned by households and renting is mostly to other household farms or to large farms.

${ }^{2}$ Exceptions are Poland and former Yugoslavia where land was used mostly by family farms.

${ }^{3}$ In this paper we do not discuss why countries have chosen different strategies in the late $19^{\text {th }}$ and $20^{\text {th }}$ century. Swinnen (2002) relates these different strategies to the initial land market situation. In France, the Netherlands and Belgium, the French Revolution in 1789 and the following Napoleonic Code in 1804 did not only abolished feudalism but also imposed different land inheritance rules (equal division among heirs). This caused a significant increase in land ownership of smaller farmers in these countries compared to England and Ireland..

${ }^{4}$ Note that for the Netherlands these protective regulations for tenants only exist for or regular rental contracts. Since 2007, liberalised rental contracts with less protective measures for tenants exist.

${ }^{5}$ In those countries, important controls existed on land ownership. For example, until recently (mid 1990s) in Ireland, the Land Commission system retained the right to purchase agricultural land and to redistribute it for the purposes of existing farm expansion. In Denmark, farmers seeking to purchase more than 30 hectares of additional land are required to seek a license from the local land authority.

${ }^{6}$ Much of the arguments here apply only to England and Wales, since Scotland and Northern Ireland had somewhat different land policies.

${ }^{7}$ See Swinnen (1999) and Swinnen and Heinegg (2002) for a political economy explanation of the different land reform choices.

${ }^{8}$ Originally, restrictions on foreign ownership of land were allowed for a transitional period of seven years (Bulgaria, Czech Republic, Latvia, Lithuania, Hungary, Slovakia and Romania) or twelve years (Poland) after the year of accession. This implies that for the Czech Republic, Latvia, Lithuania Hungary and Slovakia, the transitional period expired in 2011. However, except for the Czech Republic, all countries applied for an extension of the transitional period and they were granted an extension until 2014. 


\section{References}

Baland, J.M. \& Platteau J.P. (1998). Divisions of the Commons: A partial assessement of the new institutional economics of land rights. American Journal of Agricultural Economics, 80(2), 204-210.

Bardhan, P.K. (1989). The Economic Theory of Agrarian Institutions. Oxford: Oxford University Press.

Binswanger, H., Deininger, K. \& Feder, G. (1995). Agricultural Land Relations in the Developing World. American Journal of Agricultural Economics, 75(5), 12421248.

Boserup, E. (1965). The Conditions of Agricultural Growth. NewYork: Aldine.

Boucher, S.R., Barham, B.L. \& Carter, M.R. (2004). The Impact of Market-Friendly Reforms on Credit and Land Markets in Hunduras and Nicaragua. World Development, 33(1), 107-128.

Braselle, A.S., Gaspart, F. \& Platteau J.P. (2002). Land Tenure Security and Investment Incentives. Journal of Development Economics, 67(2), 373-418.

Carter, M.R., Fletschener, K.D. \& Blarel, B. (1994). Tenure security for Whom? Differential Effects of Land Policy in Kenya. In J.W. Bruce and S.E. MigotAdholla (Eds.), Searching for Land Tenure Security in Africa (pp. 141-168). Dubuque: Kendall/Hunt Publishing Co.

Carter, M. R. \& Zimmerman, F. (2000). The Dynamic Costs and Persistence of Asset Inequality in an Agrarian Economy. Journal of Development Economics, 63(2), 265-302.

Ciaian, P., Kancs, d. \& Swinnen, J. (2010). EU Land Markets and Common Agricultural Policy. Brussels: Centre for European Policy Studies.

Dale, P. \& Baldwin, R. (2000). Emerging Land Markets in Central and Eastern Europe. In C. Csaki \& Z. Lerman (Eds), Structural Change in the Farming Sectors in Central and Eastern Europe. World Bank Technical Paper No. 465, Washington, D. C.: World Bank.

Deininger, K. (1999). Making negotiated land reform work: Initial experience from Colombia, Brazil and South Africa. World Development, 27(4), 651-672.

Deininger, K. \& Feder, G. (2001). Land Institutions and Land Markets. In B.Gardner and G. C. Rausser (Eds), Handbook of Agricultural Economics. Amsterdam: Elsevier North Holland.

Deininger, K. (2003). Land Policies for Growth and Poverty Reduction. World Bank Policy Research Report, Washington, D. C.: World Bank. 
Deininger, K. \& Jin, S. (2003). Land Sales and Rental Markets in Transition: Evidence from Rural Vietnam. World Bank Policy Research Working, No. 3013, Washington D. C.: World Bank,

Deininger, K. (2013). Global land investments in the bio-economy: Evidence and policy implications. Agricultural Economics, 44, 1-13.

de Janvry, A. (1981). The agrarian question and reformism in Latin America. Baltimore: Johns Hopkins University Press.

de Janvry, A. \& Sadoulet, E. (1989). A study in resistance to institutional change: the lost game of Latin American land reform. World Development, 17(9), 13971407.

de Janvry, A., J.P. Plateau, G. Gordillo \& Sadoulet, E. (2001). Access to Land and Policy Reforms. In A. de Janvry, G. Gordillo , J. P. Platteau \& E. Sadoulet (Eds.), Access to Land, Rural Poverty, and Public Action (pp. 1-26). Oxford: Oxford University Press.

Dries, L. \& Swinnen, J. (2004). Foreign Direct Investment, Vertical Integration and Local Suppliers: Evidence from the Polish Dairy Sector. World Development, 32(9), 1525-1544.

Feenstra, P. (1992). The Experience with Optimum Size of Farms in Denmark. In UN, Specific Problems of the Transformation of Collective Farms into Viable Market Oriented Units (pp. 32-39). Bonn: UN Economic Commission for Europe/FAO.

Guinnane, T.W. \& Miller, R.I. (1997). The Limits to Land Reform: The Land Acts in Ireland, 1870-1909. Economic Development and Cultural Change, 45(3), 591612.

Heyman, W.J.M., Hiel, R.T.R., Kroese, E.P., van den Noort, P.C., Silvis, H.J. \& Slangen, L.H.G. (1990). Leerboek Algemene Agrarische Economie. Wageningen: Wageningen University Press.

Keefer, P. \& Knack, S. (2002). Polarization, politics and property rights: Links between inequality and growth. Public Choice, 111(1-2), 127-154.

Latruffe, L., Minviel, J. J. \& Salanié, J. (2013). The role of environmental and land transaction regulations on agricultural land price: The example of the French region Brittany. Paper presented in 30th Journées de Microéconomie Appliquée (Conference on Applied Microeconomics), 6-7 June, Nice.

Lerman, Z., Csaki, C. \& Feder, G. (2004). Agriculture in Transition: Land Policies and Evolving Farm Structures in Post-Soviet Countries. Lanham: Lexington Books.

Macours, K. \& Swinnen, J. (2002). Patterns of agrarian transition. Economic development and cultural change, 50, 365-395. 
Macours, K., de Janvry, A. \& Sadoulet, E. (2010). Insecurity of property rights and social matching in the tenancy market. European Economic Review, 54, 880899.

Maertens, M. and Swinnen, J. (2009). Trade, standards and poverty: Evidence from Senegal. World Development, 37(1), 161-178.

Meyers, W. H. \& Kazlauskiene, N. (1998). Land Reform in Estonia, Latvia, and Lithuania: A Comparative Analysis. In S.K. Wegren (Ed.), Comparative Land Reform in the Former Soviet Union and Eastern Europe. London and New York: Routledge Press.

Minten, B., Randrianarison, L. \& Swinnen, J. (2009). Global retail chains and poor farmers: Evidence from Madagascar. World Development, 37(1), 1728-41.

Petrick, M. \& Weingarten, P. (2004). The role of agriculture in Central and Eastern European rural development: engine of change or social buffer? Studies on the Agricultural and Food Sector in Central and Eastern Europe, volume 25, number 93023, Leibniz: Institute of Agricultural Development in Central and Eastern Europe (IAMO).

Platteau, J.P. (1992). Land reform and structural adjustment in sub-Saharan Africa: Controversies and guidelines. Food and Agricultural Organization, Rome: Food and Agricultural Organization.

Platteau, J.P. (2000). Institutions, Social Norms and Economic Development. Amsterdam: Harwood Academic.

Rozelle, S. \& Swinnen, J. (2004), "Success and failure of reforms: Insights from transition agriculture”, Journal of Economic Literature, 42 (2), 404-465.

Sadoulet, E., Murgai, R. \& de Janvry, A. (2001). Access to Land via Land Rental Markets. In A. de Janvry, G. Gordillo, J.P. Platteau \& E. Sadoulet (Eds.), Access to Land, Rural Poverty, and Public Action (pp. 197-227). Oxford: Oxford University Press.

Skoufias E. (1995). Households Resources, Transaction Costs, and Adjustment through Land Tenancy. Land Economics, 71(1), 42-56.

Sommer, J., Hoppe, R., Green, R. \& Korb, P. (1995). Structural and Financial Characteristics of U.S. Farms. Agriculture Information Bulletin, No 746, Economic Research Service, Washington D.C.: U.S. Department of Agriculture.

Swinnen, J. (1999). Political Economy of Land Reform Choices in Central and Eastern Europe. Economics of Transition, 7(3), 637-64.

Swinnen, J. \& Gow, H. (1999). Agricultural credit problems and policies during the transition to a market economy in Central and Eastern Europe. Food Policy, 24, 21-47.

Swinnen, J. and A. Heinegg (2002), "On the political economy of land reform in the former Soviet Union”, Journal of International Development, 14, 1019-31. 
Swinnen, J. (2002). Political Reforms, Rural Crises, and Land Tenure in Western Europe. Food Policy, 27(4), 371-94.

Swinnen, J., Vranken, L. \& Stanley, V. (2006). Emerging challenges of Land rental Markets - A review of Available Evidence for the Europe and Central Asia region. World Bank paper, Washington D. C.: World Bank.

Swinnen, J. \& Vranken, L. (2007). Patterns of Land Market Developments in Transition. LICOS Discussion Papers 179/07, Leuven: KULeuven.

Swinnen, J. \& Vranken, L. (2009). Land and EU Accession: Review of the Transitional Restrictions by New Member States on the Acquisition of Agricultural Real Estate. Brussels: Centre for European Policy Studies.

Swinnen, J. \& Rozelle, S. (2009). Governance structures and resource policy reform: insights from agricultural transition. Annual Review of Resource Economics, 1(1), 33 - 54.

Swinnen, J., Van Herck, K. \& Vranken, L. (2014), “Agricultural Land Markets Regulations in Europe”, LICOS Discussion Paper 354/14, KU Leuven, Leuven.

Tillack, P. \& Schulze, E. (2000). Land ownership, land markets and their influence on the efficiency of agricultural production in Central and Eastern Europe. Wissenschaftsverlag Vauk Kiel KG.

Toulmin, C. \& Quan, J. (2000), Evolving land rights, policy and tenure in Africa. London: IIED.

Tracy, M. (1989), Government and Agriculture in Western Europe 1880-1988, New York: Harvester Wheatsheaf.

Visser, O. \& Spoor, M. (2011). Land grabbing in post-Soviet Eurasia: The world's largest agricultural land reserves at stake. The Journal of Peasant Studies, 38(2), 299-323.

Vranken, L. \& Swinnen, J. (2006). Land Rental Markets in Transition: Theory and Evidence from Hungary. World Development, 34(3), 481-500.

Vranken, L., Macours, K., Noev, N. \& Swinnen, J. (2011). Property rights imperfections and asset allocation: co-ownership in Bulgaria. Journal of Comparative Economics, 39(2), 159-175.

Wegren, S.K. (1998). Comparative Land Reform in the Former Soviet Union and Eastern Europe. London and New York: Routledge Press.

World Bank (2005). When the Market Comes to You - Or Not. The Dynamics of Vertical Co-ordination in Agro-Food Chains in Europe and Central Asia. Report, Washington D. C.: World Bank.

Yao, Y. (2000). The development of the land lease market in rural China. Land Economics, 76(2), 252-266. 
Figure 1: Share of land rented by farmers in 2010 ( $\%$ of the utilized agricultural area)

a. All EU Member States

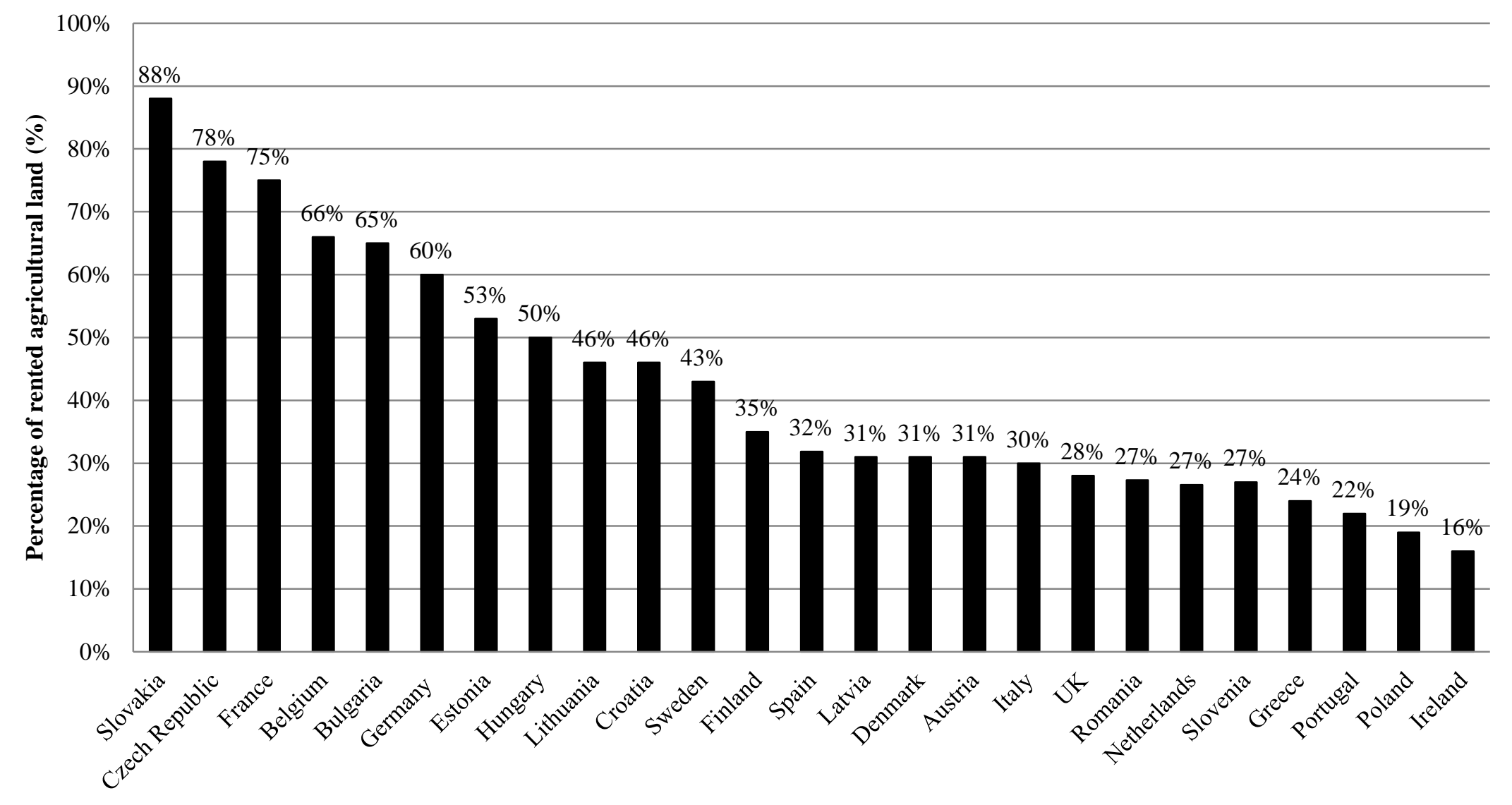


b. Western EU Member States

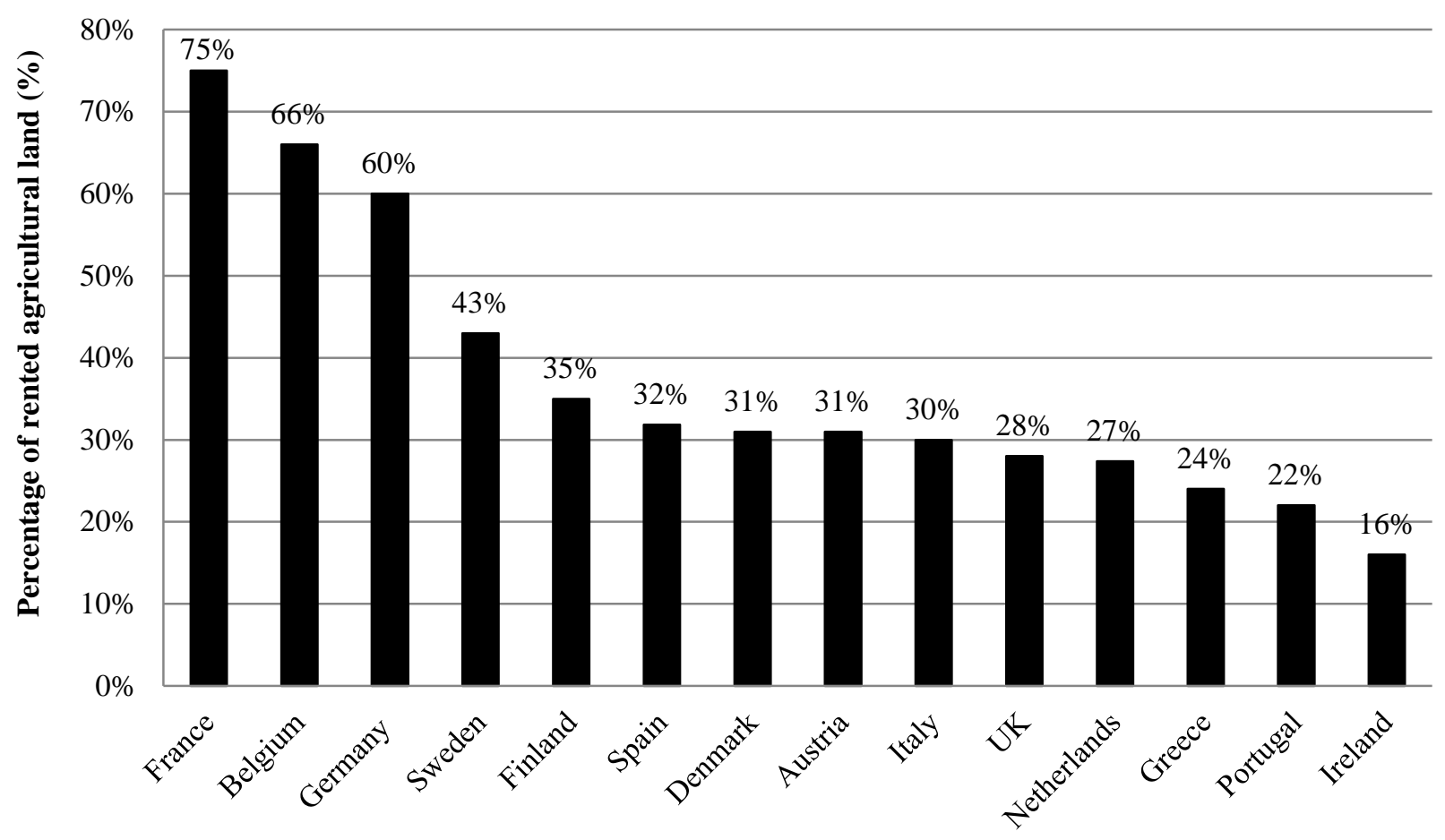

\section{c. Eastern EU Member States}

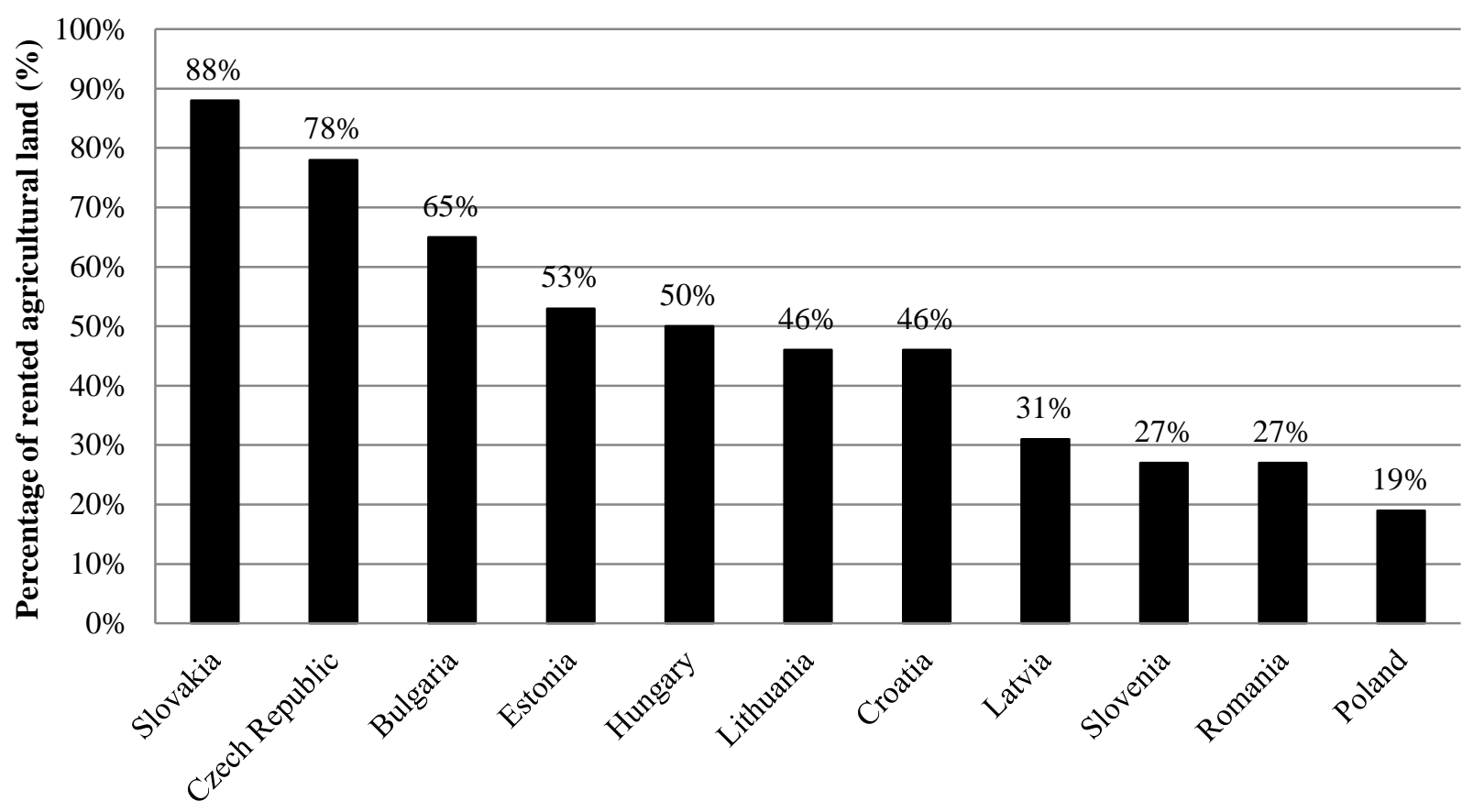

Source: Eurostat 
Figure 2: Land regulation indicators

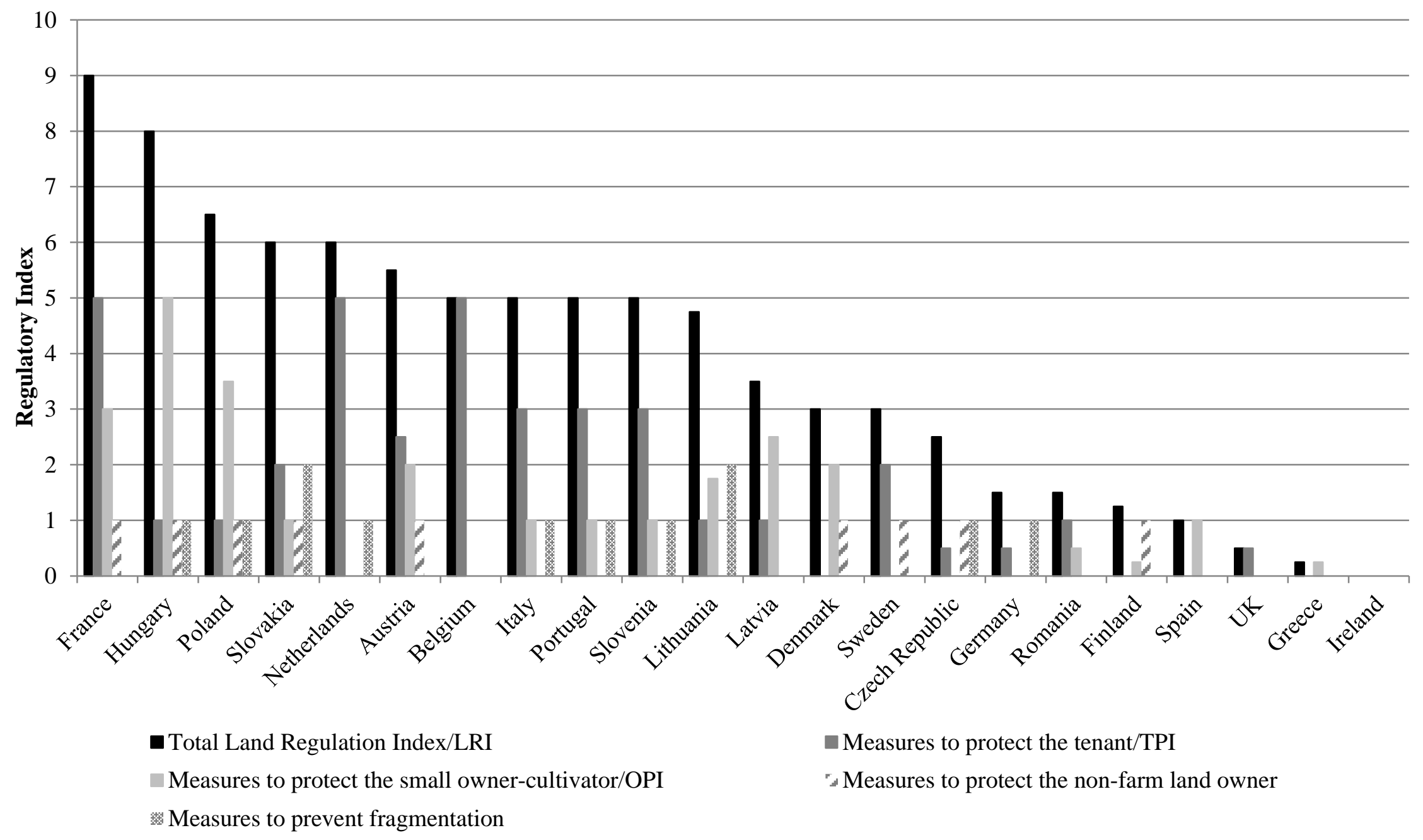

Note the indices for Estonia and Bulgaria are missing due to missing information.

Source: Swinnen et al. (2014) 
Figure 3: Tenant Protection Index (TPI) and the Owner Protection Index (OPI)

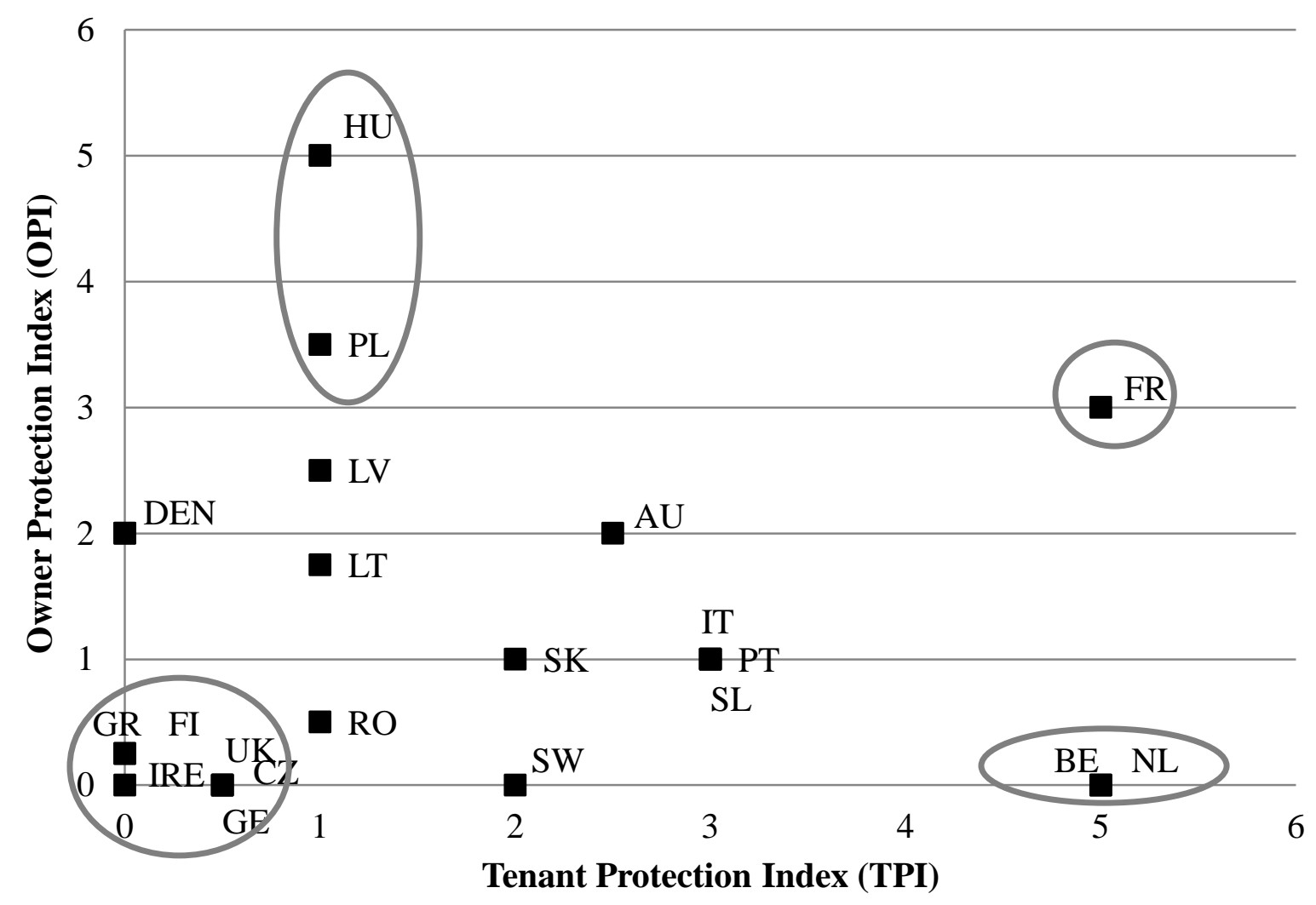

Source: Data on land regulations are obtained from Ciaian et al. (2010) and interviews with local land market experts. All data refer to the regulations that were in place in 2011. 
Figure 4: Correlation between the Tenant Protection Index (TPI) and the share of rented land

a. All EU Member States

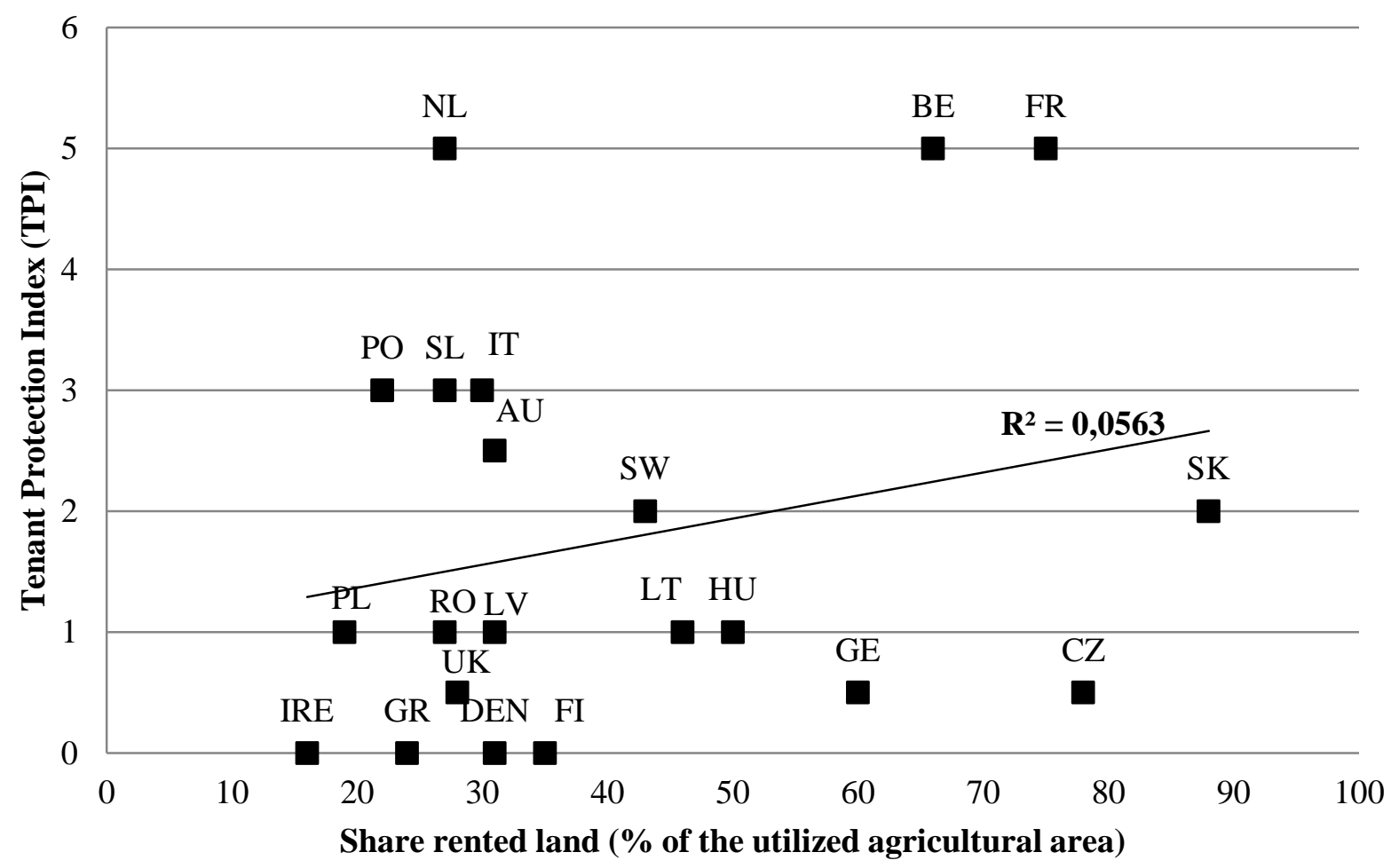

b. Western EU Member States

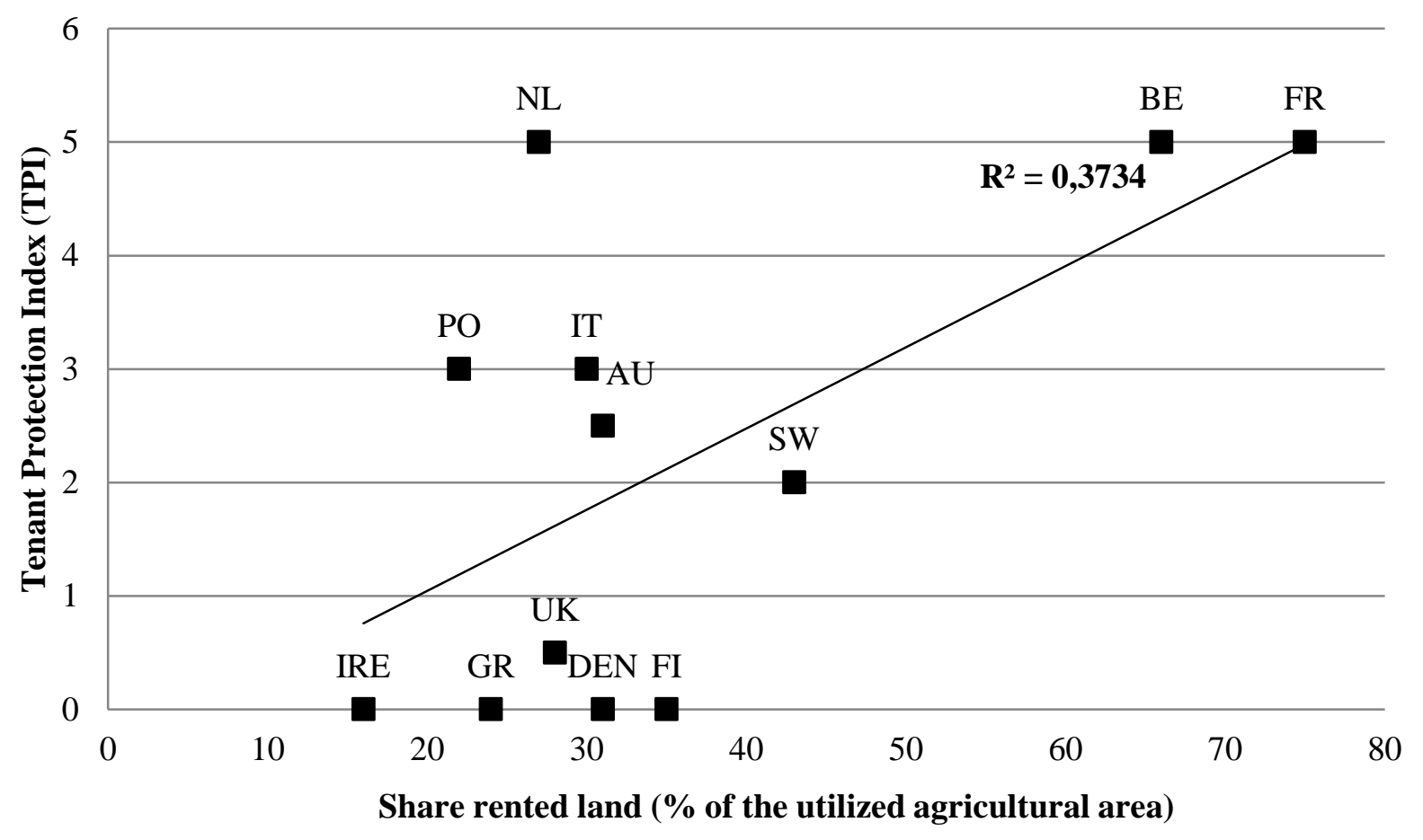




\section{c. Eastern EU Member States}

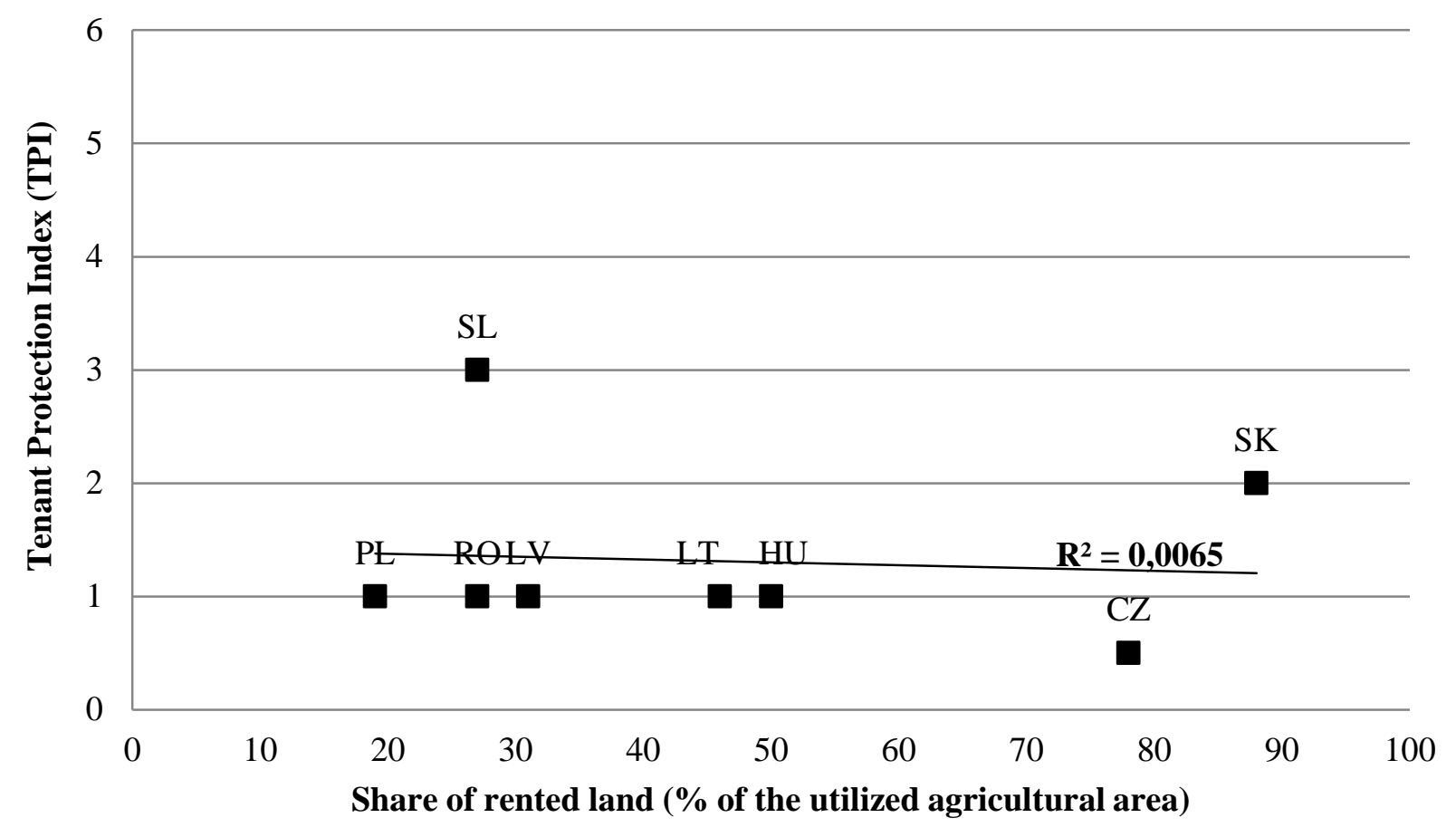

Source: Data on land regulations from Swinnen et al. (2014); data on the share of rented land (in 2010) from Eurostat 
Figure 5: Evolution land sales prices in the Netherlands with and without lease contract

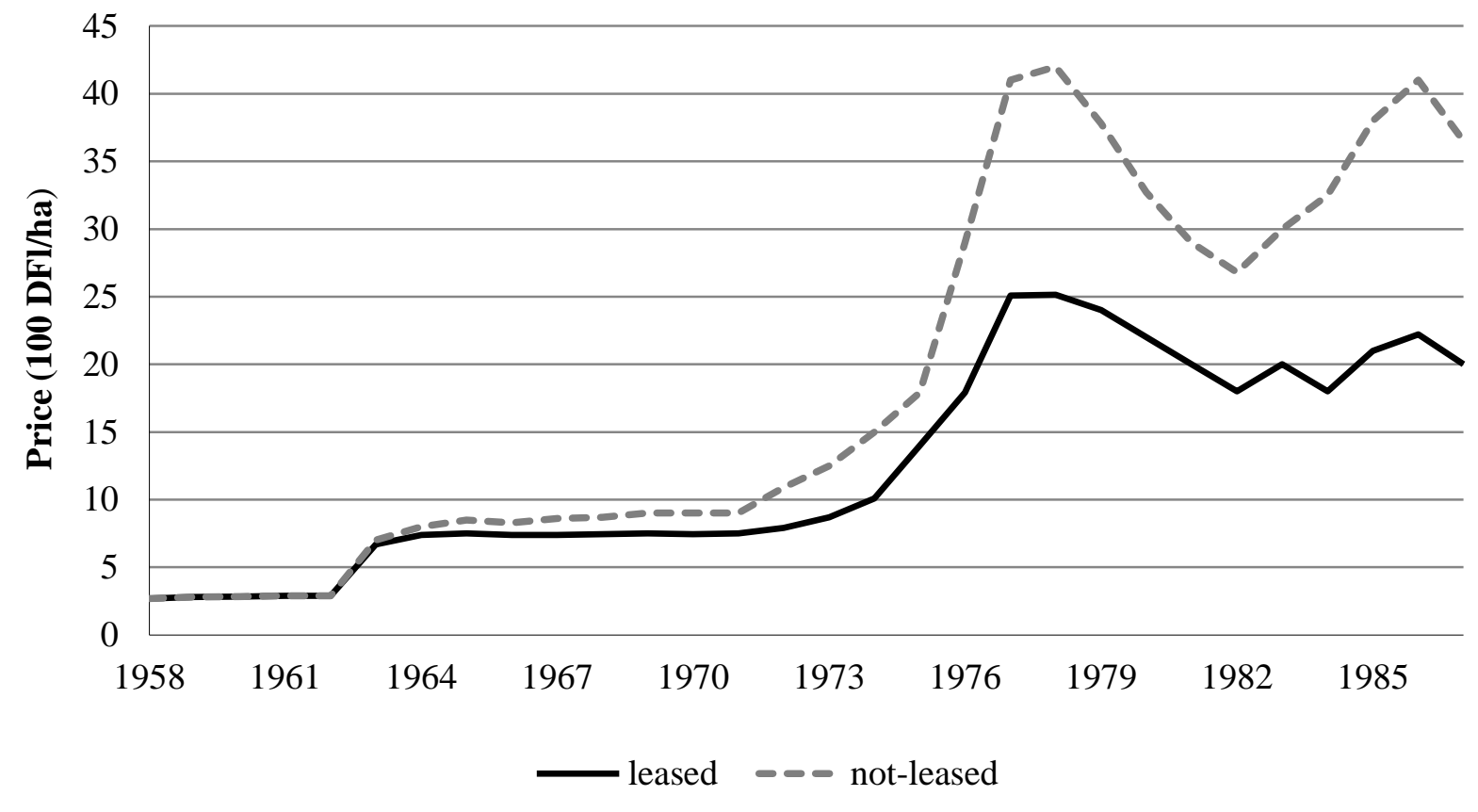

Source: Heyman et al. (1990) 
Figure 6: Evolution of land sales and rental prices of arable land in Belgium

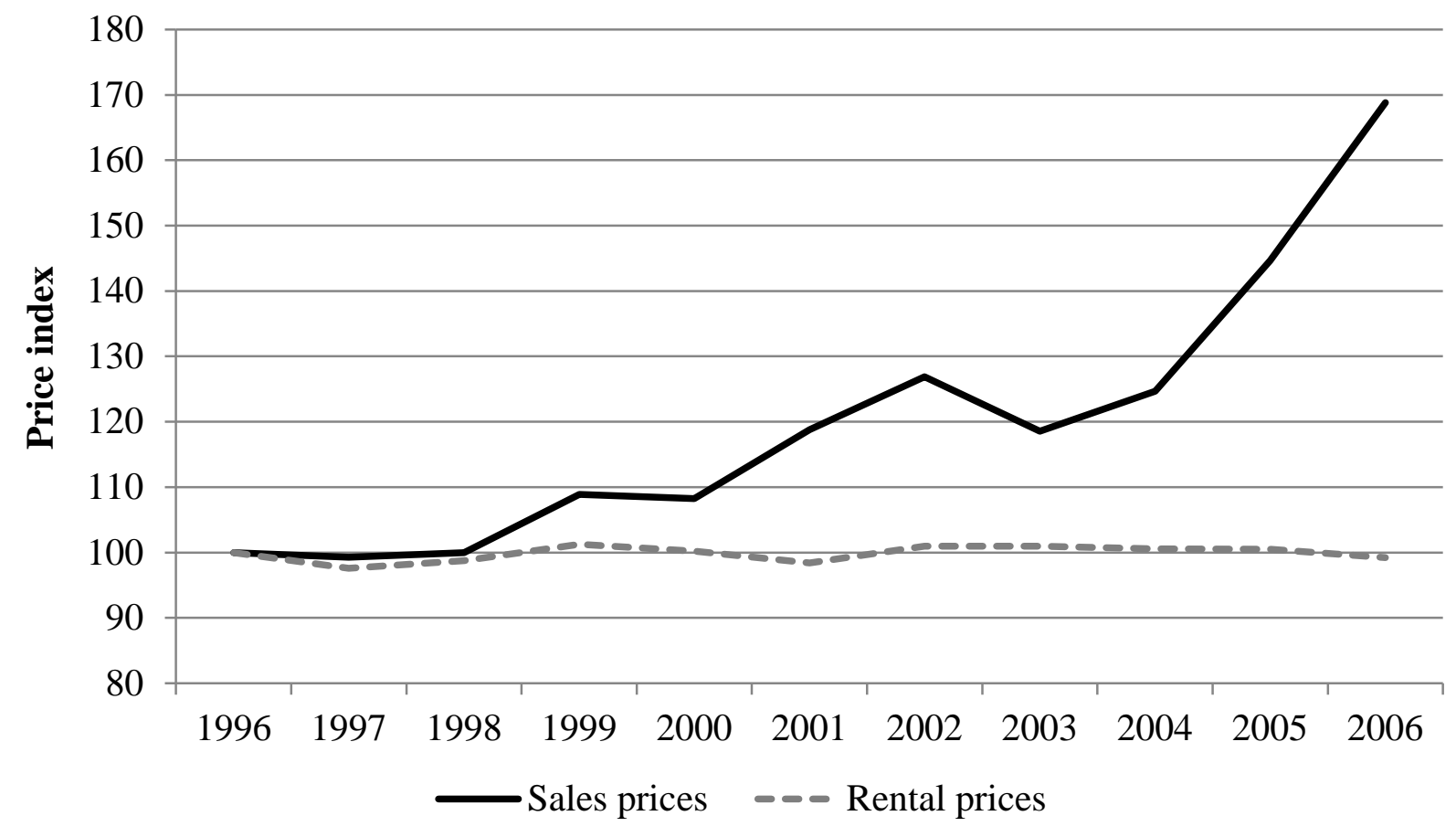

Source: National Statistics 
Figure 7: Correlation between land renting and the importance of corporate farms in Eastern EU member states in 2010)

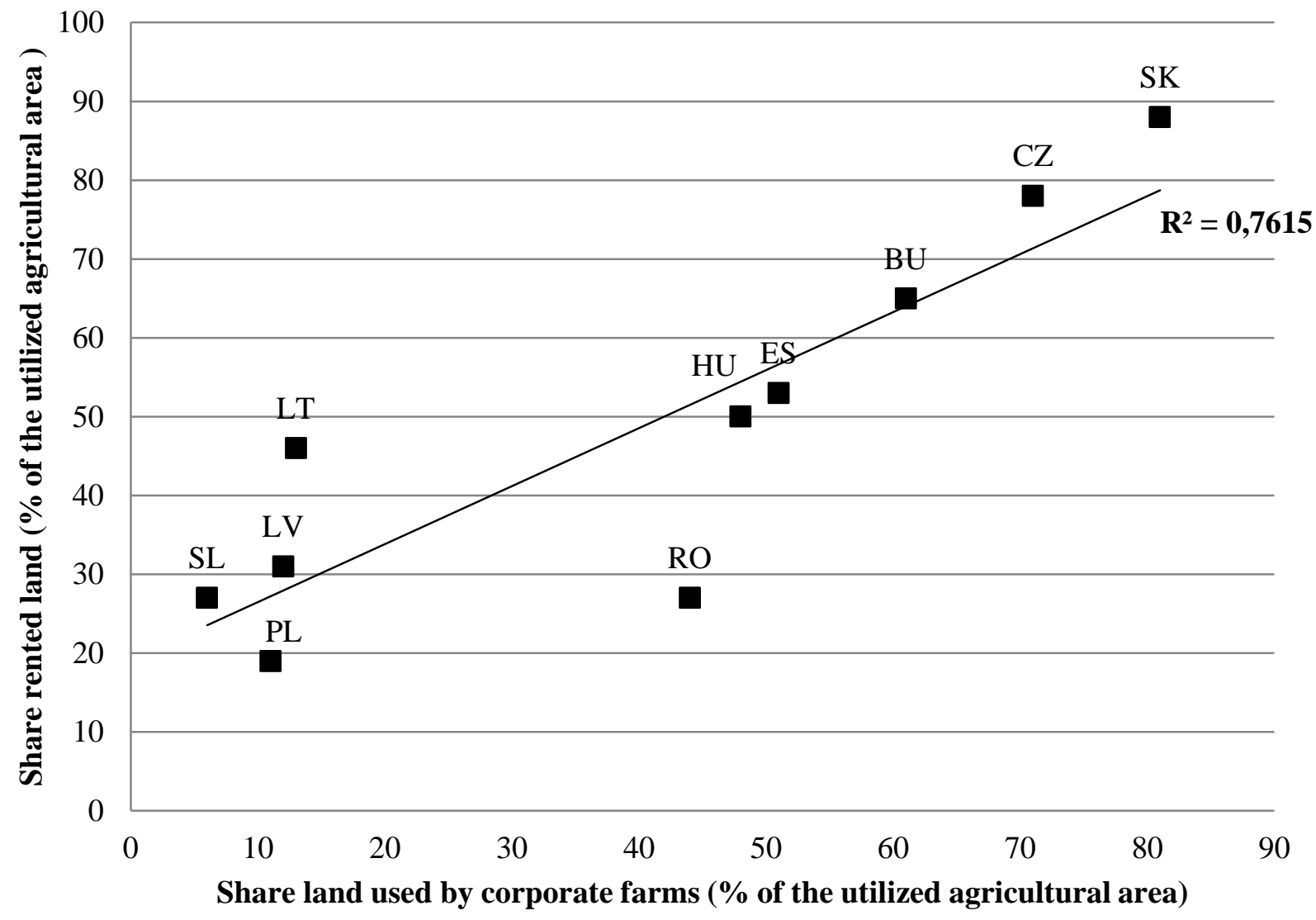

Source: Eurostat 
Table 1: Share of land rented by farmers (\% of the utilized agricultural area)

\begin{tabular}{cccccc}
\hline & Belgium & England $(*)$ & France & Ireland & Netherlands \\
\hline 1880 & 64 & $85(\mathrm{a})$ & 40 & $96(\mathrm{a})$ & 40 \\
1895 & 69 & - & 47 & - & - \\
1910 & 72 & 89 & - & 42 & 53 \\
1920 & - & 85 & - & 25 & 48 \\
1930 & 62 & 63 & 40 & 6 & 49 \\
1940 & - & 66 & - & - & 54 \\
1950 & 67 & 62 & 44 & 5 & 56 \\
1960 & 68 & 51 & 50 & 7 & 52 \\
1970 & 71 & 46 & 48 & 6 & 48 \\
1980 & 71 & 47 & 51 & 8 & 41 \\
1990 & 67 & 36 & 57 & 9 & 33 \\
2000 & 68 & 33 & 58 & 13 & 34 \\
2010 & 66 & 32 & 75 & 16 & 27 \\
\hline
\end{tabular}

Source: Swinnen (2002) and Eurostat

(*) England and Wales

(a) 1885 